\title{
Institutional Logics and Practice Variations in Sustainability Reporting: Evidence from an Emerging Field
}

\begin{abstract}
Purpose - This paper aims to deepen understanding of logics and practice variation in sustainability reporting in an emerging field.

Design/methodology/approach - This paper adopts the institutional logics perspective and its conceptualization of society as an inter-institutional system as a theoretical lens to understand reasons for the presence of and variation in sustainability reporting. The empirical findings are based on analysis of 28 semi-structured interviews with significant social actors, and extensive documentary evidence focusing on eight companies pioneering sustainability reporting in Pakistan.
\end{abstract}

Findings -This paper confirms the presence of multiple co-existing logics in sustainability practices and lack of a dominant logic. Sustainability reporting practices are underpinned by a combination of market and corporate (business logics), state (regulatory logics), professional (transparency logics) and community (responsibility logics) institutional orders. It is argued that institutional heterogeneity (variations in logics) drives the diversity of motivations for and variations in sustainability reporting practices.

Originality/value - This paper contributes to relatively scarce but growing empirical research on emerging fields. Its major contribution lies in its focus on how multiple and conflicting institutional logics are instantiated at the organizational level, leading to wide practice variations, especially in an emerging field. In doing so, it advances the institutional logics debate on practice variations within the accounting literature.

Research implications - The paper offers a deeper theoretical explanation of how various logics dominate sustainability reporting in a field where the institutionalization of practice is in its infancy.

Practical implications - Understanding the conditions that influence the logics of corporate decision makers will provide new insights into what motivates firms to engage in sustainability reporting. A broader understanding of sustainability reporting in emerging fields will foster its intended use to increase transparency, accountability and sustainability performance.

Keywords: sustainability reporting, institutional logics, practice variations, emerging field and Pakistan

Paper type: Research paper 


\section{Institutional Logics and Practice Variations in Sustainability Reporting: Evidence from an Emerging Field}

\section{Introduction}

This paper arises from an interest in variations in sustainability reporting practices. Early studies of sustainability reporting were intrigued by its patterns (e.g. Gray et al., 1995, Buhr, 1998, Adams, 2004) and motives (e.g. Buhr, 2002; Spence and Gray, 2007). Motivations refer mainly to commercial considerations articulated around the notion of the business case, in the form of both material and symbolic benefits, rather than the ethical responsibility case (Spence and Gray, 2007). Whatever the intentions of sustainability reporting, its practice appears to vary in terms of structure, standards, mechanisms and processes (Thijssens et al., 2016). Recent studies have focused on variations and on diverse motivations for sustainability reporting (e.g. Channuntapipat et al., 2019; Cerbone and Maroun, 2019). However, the link between motives and practice variations remains poorly understood in the sustainability literature, both theoretically and empirically (Contrafatto et al., 2019). This paper fills this gap.

Variations in sustainability reporting practices have generated some theoretical research interest but require further scrutiny. Legitimacy, stakeholder and neo-institutional theory have been deployed to answer questions such as why patterns of sustainability reporting vary. Legitimacy and stakeholder theories generally focus on strategic motives for reporting, whereas institutional theories explore institutional factors, focusing mainly on homogeneity and isomorphism. Interestingly, institutional heterogeneity is rarely discussed or theorized as a source of variation in sustainability reporting. This is also reflected in calls to adopt alternative institutional perspectives (e.g. Higgins and Larrinaga, 2014) in exploring how the heterogeneous societal and institutional context influences motivations for and variations in sustainability reporting.

We believe it important to examine the underlying logics of organizational actors' motivation to gain a broader understanding of practice variations and the link between motives and practice. As Greenwood et al. (2010, p.521) note, "organisational forms and managerial practices are manifestations of, and legitimated by, institutional logics. Thus, to understand how and why organizations exhibit similarity and variation in their use of such forms and practices it is necessary to trace the relationship between organizations and the logics that constitute their institutional context." This will enable us not only to demonstrate the presence of variations, but also to explain their sources. Thus, we seek to address three questions: how does sustainability reporting vary; what are the underlying logics of motivations for sustainability reporting; and how do these logics contribute to variations in sustainability reporting practice?

The link between logics and practices is well documented in the institutional literature (e.g., Lounsbury 2007; Thornton 2002, 2004). It is also well established that logics are historically contingent, and that organizations are usually characterized by multiple (and often conflicting) logics (Reay and Hinings, 2009). It would therefore be unsurprising to see organizational actors drawing on multiple logics to justify sustainability reporting practices. Consequently, such practices are unlikely to be uniform. However, their level of uniformity seems to be linked with the maturity of the field. It is argued that practice variations are relatively high in emerging fields but low in mature fields (Vican and Pernell-Gallagher, 2013; DiMaggio and Powell, 1983). Yet we know relatively little about how multiple and conflicting institutional logics are instantiated at the organizational level, leading to wide practice variations, especially in an "emerging field".

Emerging fields are characterized by loosely defined institutional arrangements, unclear institutional rules, ambiguous and highly permeable boundaries and sharp contestation between logics (Vican and Pernell-Gallagher, 2013). Thus, variations in sustainability reporting are 
likely to be more pronounced in emerging fields. Our empirical site, sustainability in Pakistan, provides us with an excellent opportunity to study this emerging field. We argue that the field of sustainability is still "emerging" in most countries around the world. Examining the emerging field of sustainability enables us not only to examine clear links between variations in sustainability reporting and their underlying logics, but also to advance the institutional logics debate on practice variations. To do this, we draw on Thornton et al.'s (2012) work on institutional logics and the institutional literature on emerging fields.

In response to a particular call to study the context of developing countries with regard to sustainability reporting, Pakistan provides a contextual setting similar to many other developing countries, as the traditional institutions of family, religion and community are important societal orders. Under the influence of these societal orders, the concept and practices of sustainability are broadly linked with philanthropic activities (Sajjad and Eweje, 2014). However, reporting on such matters is considered inappropriate, as the Islamic logic of riya (show off) and the family logic of bharosa (trust) contradict the need to disclose such practices, as expected in modern regulatory frameworks. We believe that these inherent tensions between long-established traditional institutions and the emergence of modern institutions have both direct and indirect impacts on the institutional logics and practices of sustainability reporting, which require exploration. In addition, the study on sustainability reporting in a context where very few companies comply even with mandatory disclosure requirements is indeed illuminating (Mahmood et al., 2017; Mahmood et al., 2019)

The paper is structured as follows. Section 2 presents a review of the literature, focusing mainly on the competing nature of the sustainability construct and its reporting, as well as the diversity of practices and motivations. Section 3 describes institutional logics, and Sections 4 and 5 discuss the research design and the context of Pakistan. The main empirical findings are reported in Section 6, with theoretical discussions in Sections 7 and 8, and some concluding remarks in Section 9.

\section{Sustainability and Institutional Logics}

Sustainability means different things to different people in different contexts (Bebbington, 2001). Broadly speaking, these different worldviews represent competing logics for sustainability, with differing ideas about the problems of and solutions to sustainability. The Global Reporting Initiative (GRI) has developed specific guidelines for such reporting, and the term "sustainability reporting" has been adopted by companies for reporting on economic, social and environmental performance. A plethora of research has begun to scrutinize the idea and its practices and real intentions (Cerbone and Maroun, 2019; Channuntapipat et al., 2019).

Studies of sustainability reporting have moved from examining patterns to motivations, often derived from theoretical premises. Organizational legitimacy (Deegan, 2002) and stakeholder management (Deegan and Blomquist, 2006) are cited as two major reasons for disclosures on sustainability issues. According to Buhr (2002), the decision to produce and publish the first environmental report was motivated by a desire to fill a legitimation gap and to acquire social legitimacy in order to operate. Adams' (2002, p. 245) study suggests that the main motivation for reporting is "to enhance corporate image and credibility with stakeholders". Larrinaga-Gonzalez and Bebbington (2001) find that a desire to control national environmental agendas and perceptions of corporate performance is the main motivation for organizations to disclose the largest amounts of environmental information. While most motivations relate to the symbolic benefits of sustainability reporting, research also indicates market-based rationales and a focus on material benefits (Higgins and Larrinaga, 2014). For example, in a study by Bouten and Everaert (2014), the interviewees referred to market opportunities in the form of inclusion in the sustainability index and meeting institutional investors' demands. A comprehensive list of these reasons is given by Buhr et al. (2014, pp. 
61-62), which includes moral and ethical reasons, competitive advantage, peer and industry pressure, public relations, image management, risk management, financial benefits and regulation. These observations indicate the diversity and complexity of motivations (Spence and Gray, 2007).

Studies of developing countries reveal somewhat different motivations, often stemming from their prevailing socioeconomic, political and cultural contexts. Absence or low levels of social reporting are discussed in the literature, citing reasons such as lack of community pressure, legal requirements, enforcement and resources (Lodhia, 2003; Gao et al., 2005; Belal and Cooper, 2011; Momin and Parker, 2013). The presence of social and environmental reporting is motivated mainly by external forces such as the reporting requirements of donor agencies, parent companies and foreign buyers (Rahaman et al., 2004; Adams et al., 2007; Islam and Deegan, 2010; Momin and Parker, 2013; Beddewela and Herzig, 2013). For instance, Islam and Deegan (2008) find that critical factors such as child labour and frequent accidents direct the global community's attention toward issues relating to social responsibility, and that the community imposes its responsibility expectations through buying companies. Interestingly, very few studies in developing countries find that local actors, such as local media and non-governmental organizations, play a role in enabling sustainability reporting (Soobaroyen and Mahadeo, 2016).

However, with certain exceptions (e.g. Cerbone and Maroun, 2019; Channuntapipat et al., 2019), motivations for sustainability reporting have not been well explored alongside variations in reporting. Variations in practices may be explained by the voluntary and unregulated nature of reporting, but different world views and institutional beliefs may also create such differences (Byrch et al., 2007). According to Adam and McNicholas (2006), the views and attitudes of those involved in reporting appear to influence reporting practices, depending on the extent to which information gathered for sustainability reporting is used in decision making, the functions, departments and staff involved, and formalization of the sustainability reporting process. Nevertheless, variations in reporting are not a major focus of the empirical literature. To the extent that variation is examined, it is typically conceptualized as stemming from actors' strategic use to resist institutional pressures (e.g., Oliver, 1991), or pretending to act in accordance with institutional demands while pursuing their own agendas. Yet none of these studies focuses on the underlying logics of varied motivations and reporting practices.

Institutional logics have been advanced in management and accounting studies, including research on sustainability (Madsen and Waldorff, 2019). Interplays between logics and organizational responses, including practice variations, are well documented (Herremans et al., 2009; Ezzamel et al., 2012; Lander et al., 2013; Guerreiro et al., 2012; Conrath-Hargreaves and Wüstemann, 2019; Malik and Nicholson, 2020). More recently, attention has focused on how organizations actively manage institutional complexity in the face of conflicting logics (Lepori and Montauti, 2020) and prioritize a particular logic over others when faced with disasters, instability and external pressures (Safari et al., 2020; Golyagina, 2019; Yee, 2020; ConrathHargreaves and Wüstemann, 2019).

Sustainability researchers have deployed the notion of logics to understand the motivations underlying various sustainability initiatives (Kok et al., 2019; Cerbone and Maroun, 2019). For instance, Contrafatto et al. (2019) argue that institutional logics are very useful for deciphering the uneven development of sustainability reporting practices, but note a relative dearth of research on the dynamics, logics and conditions of the evolution of sustainability reporting, especially in developing countries (Jamali et al., 2017). Similarly, Cerbone and Maroun (2019) argue that how logics are instantiated may explain the considerable variation observed in integrated reports. Given the large number of studies on institutional logics and accounting practices, we know surprisingly little about how institutional logics drive practice variations in 
an emerging field. This paper speaks to these omissions. The next section elaborates on institutional logics, emerging fields and practice variations.

\section{Institutional Logics, Emerging Fields and Practice Variations}

Thornton et al.'s (2012) work on institutional logics conceives society as an inter-institutional system. The most recent development of this framework comprises seven institutional orders - market, corporation, profession, state, family, religion and community - theorized across nine categories that collectively constitute the logics of these institutional orders (Thornton et al., 2012, p. 73). Institutional orders can be understood as mega-institutions or societal orders, which are guided and organized by their distinct logics. As part of a social system, organizations and individuals are influenced by these institutional orders and their underlying logics. Each order represents a different set of expectations (logics) and shapes in different ways how logics of action are perceived and experienced. This means that logics vary with the institutional order, with potentially multiple institutionally-based logics in a given context (Lounsbury, 2008), which may lead to diverse actions arising from different reference systems for such actions (Goodrick and Reay, 2011).

The link between logics and practices is discussed in institutional studies (e.g., Thornton, 2002; Lounsbury and Crumley, 2007). Institutional analysis explains how organizations are embedded in fields that constitute the constellation of logics and practices. Organizations draw on these logics and practices in order to construct legitimate practices. How and why they draw on some logics and practices rather than others depend on organizational dynamics and the maturity of the field. The institutional logics perspective explains that, depending on organizational characteristics and experience and how they are situated, some logics are more accessible than others. These accessible logics and how they are used by organizational actors shape organizational rationality and actions. In this regard, an important theoretical construct connecting organizational analysis with institutional analysis is the organization's situational context including the state of the field, which is an important variable because it reveals external stimuli (Ocasio, 2011). Certain features of the organizational environment in this situational context may attract managers' attention. Thus, institutional logics are best suited to providing robust explanations of the sources of variation in practice.

By focusing on how fields are composed of multiple logics, and thus multiple forms of institutionally-based logics, this approach to institutional analysis may provide new insights into variations in and dynamics of practice, as multiple logics may create diversity in practice (Conrath-Hargreaves and Wüstemann, 2019). Drawing on the institutional logics perspective, we conceive sustainability reporting as a form of corporate practice socially constructed by subjects, such as sustainability practitioners and stakeholders, through constellations of institutional logics. However, both the subjective meanings and material practices of logics are enabled and constrained by higher-level institutional order, which must be explored in order to understand the social construction process of sustainability reporting. The institutional logics perspective provides a conceptual basis for analyzing the social construction of the material and symbolic practices of sustainability reporting through institutional orders and their logics. Research adopting this approach looks for variations in practices and links such variations to broader logics.

However, these multiple logics evolve in a societal context that varies from one field to another field. Contextual understanding of the logics and their impact on organizational practices is therefore important. Such understanding is even more important in the context of emerging fields, as emerging constellations of institutions shape logics and practices in somewhat different ways (Jamali et al., 2017). Thus, there is likely to be uncertainty about which institutional logics shape sustainability reporting in Pakistan, as the field is still in its infancy. 
DiMaggio and Powell's (1983) works on institutional theory distinguish between mature and emerging fields. This topic is further explored in more recent institutional studies (Vican and Pernell-Gallagher, 2013). Emerging and mature fields are distinguished in terms of levels of interaction, defined structures of domination, information sufficiency and the presence of a common purpose among participants. More interaction between field players leads to the institutionalization of practice and maturity of the field. However, in emerging fields, due to lack of established rules, there is little interaction among the organizations that results in weak network and lack of coordinated action (Gray, 1985). Mature fields are characterized by the domination of a few players working together to establish appropriate institutional norms within the field. However, in emerging fields, no single group of organization dominate the institutional field. Rather, emerging fields are subject to large number of actors with varying opinions about new practices (Purdy and Gray, 2009).

In mature fields, greater information sharing across organizations maintains stability. In contrast, in emerging fields, information accessibility is limited. As a result, there is sense of uncertainty among organizations in an emerging field. This uncertainty gives rise to ambiguity in the institutional norms and rules that define legitimate actions and acceptable behaviour (Navis and Glynn, 2010). Similarly, in an emerging field, the participants do not share a common identity, and accordingly the field lacks a common purpose for its existence. Emerging fields are subject to complex power dynamics as actors compete to gain adherents to their logics (Purdy and Gray, 2009). Conflict resolution is difficult, since "the greater the range and intensity of schisms, the more difficult will be the task of developing acceptable norms" (Greenwood et al., 2002, pp.75-76). Mature fields are hierarchically distributed, with some actors exercising influence over the norms governing legitimate behaviour, whereas in emerging fields, structures of domination (Giddens, 1979) have not yet been established. Nevertheless, organizations in newly emerging fields must contend with existing institutions (Holm, 1995; Dacin, 1997) that are likely to produce disparate organizational practices. In this paper, we seek to examine these variations in relation to sustainability reporting in Pakistan.

We focus on the logics instantiated by organizational actors when explaining the presence of and variations in sustainability reporting practices. Given the level of maturity of the sustainability field, we expect organizational actors to instantiate various institutional logics to inform their sustainability agenda. In order to understand articulations of logics and their subsequent impact on practice, we complement the voices of subjects (sustainability practitioners) with documentary evidence, including sustainability reports. This is further elaborated in the research method section.

\section{Research Methods}

Owing to the porous nature of the "emerging field" of sustainability reporting, recognizing key actors is difficult, as many actors are able to easily enter and exit and influence the field with their baggage of logics and practices (Vican and Pernell-Gallagher, 2013). To identify these actors and develop a topic guide, we conducted a pilot study involving two interviews, one with a leading sustainability reporting consultant and the other with the CSR manager of a leading firm reporting on sustainability. The professional connections of the first author provided us with the necessary access to these organizations.

Based on insights from the pilot study and further exploration of the documentary evidence, a list was developed of all significant social actors believed to shape sustainability reporting practices in Pakistan. This process of identifying significant actors was simultaneously informed by the literature review and the theoretical framework. The literature review revealed the importance of interviewing both stakeholders and organizations involved in the practice in order to gain a comprehensive understanding. Since the theoretical framework conceptualizes society as comprising seven mega-institutions (family, community, state, 
market, profession, corporations, religion) influencing organizations, it was necessary to conduct interviews with a diverse range of actors who could contribute insights into the influence of these institutions on sustainability reporting practices.

Twenty-eight interviews were conducted with key social actors. Of these, 13 were conducted with significant field players, and 15 with senior-level corporate managers of organizations reporting on sustainability. All interviews were conducted over a period of four months in three cities (Karachi, Lahore and Islamabad). These interviews followed the topic guide and ranged in length between 45 and 90 minutes. All interviews, apart from two where case notes were taken, were recorded with the interviewees' consent. All but two interviewees were interviewed once. At the end of each interview, we shared our understanding with respondents to provide them with an opportunity to endorse or amend what they had said.

The data sources for this research also included documents. Qualitative analysis of documents focused on "identifying important actors", important events, structural conditions, external forces, "tracking discourse", and "tracking practices". The first step in identifying structural conditions was a review of the historical literature on the various societal logics of Pakistan, and (direct or indirect) external influences on their evolution. The next step was to develop a better understanding of the structural conditions faced by reporting organizations. We also collected documents relating to the state of sustainability reporting in Pakistan that had appeared in national and international media, for example in the form of research papers, reporting awards, conferences, etc. Institutional logics can often be located in field-level discourse, such as in trade association and industry media. These news reports proved very useful for developing a general understanding of the structural conditions faced by reporting organizations, as well as for tracking discourses and practices relating to sustainability reporting in Pakistan. Another important source of information was official documents of the reporting organizations, including sustainability reports, annual reports and magazines.

After collecting the data, the next stage was to analyze the interview and documentary evidence. This analysis took two forms: the first sought to uncover Pakistan's institutional orders, and the other involved uncovering institutional logics and practices relating to the "emerging field" of sustainability reporting in Pakistan. According to the research traditions of the institutional logics perspective, institutional orders include societal logics, external forces and the resource environment, which shape field-level institutional logics. These conditions establish the unique context, which is very important for understanding individual and organizational behaviour, "as it both regularizes behaviour and provides opportunity for agency and change" (Thornton and Ocasio, 2008, p.102). Through analysis of the interviews and documentary evidence, the emergence and development of institutional orders and the role of external influence, along with their implications, was documented in the form of narratives.

In the first stage, all relevant outputs and findings from the interviews were translated (if necessary) and transcribed. These were organized into themes (codes). In this analysis, we constantly reworked our coding scheme/thematic analysis to capture nuances in the data and to theorize the process of doings, (re)actions and strategies as the theory prescribes. To identify different institutional logics we used pattern matching, which is an analytical technique used by previous researchers to capture institutional logics (Reay and Jones, 2015). This involves analyzing the data to identify specific instantiations of institutional logics, and then comparing/matching these with predetermined elements of institutional logics. The presence of multiple logics explains why sustainability reporting practices vary, as multiple logics may create diversity in practice. Variations in management practices are linked to broader institutional logics.

To capture similarities and differences in reporting practices and to provide insights into the logics underlying these practices, we performed a qualitative content analysis of sustainability reports. This involved examining specific dimensions of sustainability reporting 
practices and mapping them against the ideal-type institutional logics of such practices. These ideal types were developed from the literature and the theoretical framework. This paper focuses on four dimensions: approach, strategy, structure and processes. These four dimensions and items within them were then matched with different institutional logics to develop ideal types.

Owing to differences in their experiences, knowledge and reflexive abilities, social actors may or may not be aware of the structural conditions affecting their actions; however, researchers can trace these structural conditions from their accounts. In order to ensure the validity of our research, we triangulated the results of our interviews with our findings from other data sources and the established literature (Yin, 2014). In case of inconsistencies between the different sources, we contacted the interviewees again to seek clarity. Internal validity was also achieved through pattern matching, which involves comparing empirical data with predetermined theoretical constructs and with previous studies. Overall, our data analysis helped us to understand why organizations vary in their logics and practices of sustainability reporting.

\section{The Context of Pakistan}

Inspired by our theoretical framework, this paper discusses Pakistan's key institutional orders. Two traditional institutions in Pakistan are important: family and religion. Most businesses, including stock exchange-listed companies, are family-owned, reflecting societal workings in Pakistan. Family as an institution is characterized by a kinship (biradiri) logic, whereby defence of the honour and interests of the kinship group usually outweighs loyalty to a party, to the state, or to any code of professional ethics (Lieven, 2012). This also comes with secrecy, with serious implications for disclosure practices. The Islamic tradition is another important institutional order shaping the politics, regulation and socio-cultural life of the people of Pakistan (Lieven, 2012). Although Islam encourages responsibility for the wider community, it discourages disclosure of such actions to demonstrate modesty. Under the religious logic, individuals and companies are expected to do good things for society and environment, without necessarily disclosing them. At the same time, companies and individuals are more likely to draw on a community logic when disclosing sustainability practices. The Pakistani media, which have emerged as an important player in raising public awareness of various issues, provide coverage of issues relating to social responsibility and sustainability (Khan and Khan, 2004).

Modern institutions such as the state and its regulatory power are constituted against the backdrop of the traditional institutions of family and religion. Clientelism, as an exchange of material favours for political support among actors with asymmetric power, has been the principal hallmark of Pakistani politics. At the local level, access to this patronage is acquired by people using their position within a kinship network to mobilize support for a politician who, when elected, pays them back in various ways (Lodhi, 2011). This makes the Pakistani state very weak, and has important implications for the regulatory regime that the state seeks to impose on business (Lieven, 2012). The elitist capturing of a weak state and its underlying logic of clientelism rooted in patronage and kinship suggest that there is little room for mandatory corporate social responsibility. Thus, compliance with voluntary sustainability reporting must be understood through, for example, corporate and professional logics.

Accountancy as a profession in Pakistan is shaped by its colonial past and the involvement of international financial institutions. British rules, regulations and trained accountants were major influences on early accounting practices (Ashraf and Ghani, 2005). In addition, through various reforms, international financial institutions have also shaped the accountancy profession. In the absence of any national accounting standards, Pakistan adopted International Accounting Standards immediately after their release in 1974. The corporate sector is generally 
weak and underdeveloped (Malik, 2014). Many businesses thrive in the informal or non-listed sector. It is estimated that there are around three million undocumented businesses, mostly SMEs, working as sole proprietorships or partnership firms. Of these, only 60,000 are registered corporate entities, accounting for only two per cent of businesses in Pakistan. Among these registered corporate entities, only 560 are listed companies. The remaining companies are unlisted, and most are family-owned and registered as private limited companies. In recent years there has been an increasing trend toward corporatization. This means that a larger proportion of Pakistan's corporate shareholding resembles a concentrated family ownership structure, in which the majority shareholders not only retain control of the company but are also engaged in managing it. This concentrated ownership results in insider control and determines the corporate ideology and culture, which is very centralized. Familial ties and centralized management culture are the norm when making many decisions, including corporate giving and CSR initiatives.

\section{Variations in Sustainability Reporting}

This section addresses the question of how sustainability reporting varies in an emerging sustainability field in Pakistan. Deloitte's (2012) study of sustainability reporting at the KSE (Karachi Stock Exchange) reveals that 19 companies listed on the KSE 100 index were either issuing standalone sustainability reports or presenting information on sustainability as part of other information within their annual reports. Sustainability reporting in Pakistan has gained some momentum, mainly as a result of various institutional and regulatory developments. ${ }^{1}$ These recent developments have contributed to increasing key stakeholders' awareness of sustainability reporting. Multi-stakeholder initiatives ${ }^{2}$ have been active in Pakistan's corporate world, and the Pakistan Environmental Reporting Awards (PERA) were introduced in 2002, the number of submissions for which rose from 11 to 109 between 2002 and 2013. While most entries have been for the category of best environmental reporting, a handful of companies (currently around 20) have made submissions for best sustainability awards.

With a small number of companies engaging with sustainability, drawing on the interviews and documentary analysis, we found that companies' sustainability reporting practices vary significantly. To understand these variations, we investigated several dimensions of reporting using the framework developed by Thijssens et al., (2016). Broadly, these dimensions relate to the sustainability reporting approach, the emphasis of the sustainability strategy, the leading department involved, the involvement of consultants, sustainability reporting guidelines, sustainability reporting assurance, stakeholder engagement and sustainability targets. Table 1 summarizes these practices and variations for eight reporting organizations considered to be pioneers of sustainability reporting in Pakistan and exemplars of best practice in sustainability reporting.

\section{[Insert Table 1]}

Table 1 demonstrates that the companies' practices varied on different dimensions of sustainability reporting. The departments involved in developing sustainability reports varied across our sample, including Corporate Communications (A, D, E), Public Relations (B), Health, Safety, Environment and Quality (C), Corporate Branding (F) and Corporate Social Responsibility $(\mathrm{G}, \mathrm{H})$. Companies' practices varied in terms of the involvement of consultants. In five (A, B, F, G and $\mathrm{H}$ ) of the eight companies, consultants were involved in various processes relating to sustainability reporting, including content writing and stakeholder engagement. The types of consultants also varied, including a CSR consultancy firm (A), a PR agency (B), a management consultancy firm $(\mathrm{G})$ and Big Four accountancy firms (F and $\mathrm{H})$. GRI guidelines were being followed by most companies (A, C, F, G and H). However, rather 
than GRI, some companies (especially MNCs - B, D and E) were following the requirements and sustainability frameworks of their respective head offices. Only one company (D) mentioned in its sustainability report local guidelines on CSR and sustainability issued by the Securities and Exchange Commission of Pakistan. Some companies (e.g. C) were following multiple guidelines.

Although quantified targets and stakeholder engagement processes are considered to be an important mechanism in sustainability reporting, only a few companies provided quantified targets (A, C, E and G) and explanations of stakeholder engagement processes (A, C and G) in their reports. In terms of the process, companies' practices varied from outside-in to inside-out approaches to sustainability reporting. Companies were mainly following an outside-in approach, driven by stakeholders, public relations, head-office requirements and sustainability guidelines

As illustrated in Table 1, sustainability reporting practices do not adhere to a particular norm but exhibit multiple shapes and forms of reporting format and approach. More importantly, we found companies articulating diverse motivations for producing sustainability reports. It was unsurprising, but indeed interesting, to find interviewees citing a whole host of motivations for engaging with the sustainability agenda. We found no apparently dominant logic underlying their motivations for sustainability reporting. Motivations cited by organizational actors included "managing stakeholder concerns", "image management", "brand building", "sustainability leadership", "showcasing responsibility and sustainability", "regulatory compliance" and "measuring the impact of sustainability initiatives and transparency in business improvements". Given these numerous strands of motivation, practices varied. For instance, companies motivated by image management tended to take a public relations approach to sustainability reporting, whereas companies motivated by leadership position or competitive advantage tended to take a stakeholder approach. This is discussed further below.

\section{Sustainability Reporting: Underlying Logics of Motivation}

Companies championing sustainability reporting in Pakistan were pushing further in taking their reporting to the next level of 'integrated reporting'. Given this background, it is a very pertinent to ask why some companies are pushing the sustainability reporting agenda while most are completely ignoring it. Drawing on institutional logics and our empirical accounts, we shed light on the logics deployed and prioritized in rationalizing the sustainability agenda.

\section{[Insert Table 2]}

Table 2 illustrates motivations for sustainability reporting and their underlying logics. We find four institutional logics instantiated by organizational actors to explain their motivations for sustainability reporting practices.

\subsection{Practice Driven by Business Logics: Market and Corporation}

In our interviews, organizational actors often revealed a host of motivational factors influencing their engagement with sustainability reporting in a context where this is an exception rather than the rule. For instance, some interviewees highlighted economic gains, reputational gains, branding, shareholder value, competitiveness and global market integration. Reflecting on our concept of institutional logics, we argue that these motivations are rooted in the business logic of sustainability reporting.

We conceive business logics as a combination of market and corporate order (Currie and Spyridonidis, 2016; Arena et al., 2018; Jamali et al., 2017). The market focuses on economic 
gains and legitimizes profit-seeking behaviour in business practices (Thornton et al., 2012). It is assumed that companies will address sustainability issues only if this positively affects their financial performance, for example through profits and shareholder value (Schaltegger and Hörisch, 2017). The corporate order complements the market in focusing on economic value. Both corporate and market order combined in business logics were reflected in the sustainability reporting practices of some of the companies investigated.

One of the central messages from our discussions with the main protagonists was that there is a business case for sustainability. For example, "the process of producing reports enables businesses to internally identify operational inefficiencies, cut waste and save money for the company" (Executive CSR, Company G, Fertilizers), and "good companies report on their sustainability issues and set targets for improvements, for example about energy conservation, water consumption. Then they use different ways to reduce them and this leads to direct cost benefits" (Partner, Managament Consultancy Firm). In a similar vein, companies that reported on socially and environmentally responsible strategies justified them as "making good business sense as well as making [a] positive contribution to the society [and] environment" (Executive Finance, Company H, Fertilizers).

Many interviewees talked about "brand" and "image". For example, "These things provide credibility and enhanced image and play their role when we do corporate branding and image management. It adds value to your overall business" (Manager Corporate Communications and Public Affairs, Company E, Chemicals), and "Sustainability reporting brings the organization into a league of companies where everybody looks at the organization differently as a more responsible, more ethical organization. It adds to the corporate brand of the organization and makes you employers of choice, [the] supplier of choice" (Manager Brand and Corporate Communication, Company F, Cement). Business logics, as reflected in these quotes, include the long-term and intangible benefits of stakeholder management, corporate image, competitive advantage, corporate branding and sustainable value creation (Parker, 2014).

In addition, there was a desire among corporations to be leaders. This took the form of thought leadership - "One of our sustainability objectives is to emerge as a thought leader ... we want to showcase to the community and to the relevant people as to what our company can do in terms of the knowledge base of the economy" (Head of Corporate Communication, Company A, Fertilizers); practice leadership - "We want to be a leader in the practice of sustainability reporting in order to educate others in the industry as to how to become transparent and responsible" (Head of Corporate Communication, Company F, Cement); and market leadership - "Our company is driven by the motivation to lead in the market. All decisions are taken to ensure that this position is maintained" (Manager, Company C, Petroleum). Among the leaders in sustainability reporting, an element of prestige was found at both personal (managerial) and corporate levels. This prestige was enhanced by gaining reporting awards. Companies' management felt proud when they went to award ceremonies and received awards. This prestige was believed to raise both managerial and corporate profiles and boost corporate executives' egos (Spence, 2009). Connected with this was a desire to control the discourse of sustainability and its reporting in Pakistan. Managers of leading corporations now sit on the judging panels of reporting awards, sponsor conferences and workshops on sustainability reporting, and are involved with various social actors (government, profession and community) in shaping the future practice of sustainability reporting.

Interestingly, business logics are promoted by professional bodies, as illustrated in ACCA research reports. It is well understood among sustainability practitioners in Pakistan that sustainability reporting provides companies with far better access to foreign markets and capital, as well as operational efficiencies and cost savings (Waheed, 2005). The most common enactments of the business logic for sustainability reporting are sustainability communications 
by firms reporting on sustainability, and professional reports and articles published by professional associations supporting these initiatives. Not surprisingly, market-oriented discourses appear to be consistent with a more established/mature sustainability field (Bebbington et al., 2008; Van Bommel, 2014; Arena et al., 2018; Jamali et al., 2017).

\subsection{Practice Driven by Logics of Transparency: Profession}

A central message of many protagonists of sustainability in our field was the logic of transparency. Key motivational factors underlying this logic included maintaining global standards, a transparent management style, professionalization and sustainable value creation. This is unsurprising, because the sustainability reporting discourse is seen as "part of being transparent and engaging the stakeholders" (Herremans et al., 2009) as it aims to increase transparency about operations and impacts (Higgins and Coffey, 2016; Maas et al., 2016). Crucially, professional associations aid transparency projects by deploying experts and establishing norms in the field of accounting (Carlsson-Wall et al., 2016). Accounting-based professional associations and firms are key actors in driving sustainability reporting around the globe. Being associated with professional bodies drives companies to adhere to international reporting frameworks such as those proposed by the GRI (Arena et al., 2018).

Thornton et al. (2012) argue that an important rationale for practice is to increase personal and professional reputation. Sustainability reporting is clearly seen as a symbol of management excellence and professionalism (Schaltegger and Burritt, 2018; Jamali et al., 2017). For social actors embedded in the profession, their source of legitimacy is personal expertise, and their source of identity is association with the quality of craft and personal reputation. Professional sustainability practitioners view reporting as important not only for firms' reputation and prestige but also for the individual reputation and prestige of managers, in the form of praise from stakeholders, participation in award ceremonies and interviews for prestigious manager magazines, glossy brochures, press releases and VIP events.

Local and international professional associations and networks drive the sustainability reporting agenda in Pakistan in various ways, such as through consultancy, reporting awards, organizing regular workshops and conferences on sustainability reporting, membership of the United Nations Global Compact (UNGC) and writing monographs and professional articles. Various complex and specialist CSR- and sustainability-related standards and guidelines are transmitted through these professional networks and associations. This is unsurprising, as research has demonstrated that professional associations provide normative references for individual practitioners, such as communication, CSR, sustainability and environmental managers (Arena et al., 2018).

We engaged with these actors in order to grasp the discourses employed in the field. The logics of "transparency", "sustainable value creation" and "global standards" were constantly articulated as promoting sustainability reporting. For example, "If you are looking to attract foreign investment, there is no point in inventing your own standards. You have to demonstrate that you have adopted global standards" (Country Head, Foreign Professional Accountancy Body), and "Determining opportunities in societal issues and converting these opportunities to generate profitable innovation is the most important step on the sustainable value creation" (President, Local Professional Accountancy Body). It is important to note that both accounting ${ }^{3}$ and non-accounting ${ }^{4}$ professionals employ the transparency logic for sustainability reporting. Accounting professionals focused particularly on transparency relating to business improvements and sustainable value creation (alignment with business logics), whereas as nonaccounting professionals focused on transparency with regard to accountability and societal impacts (alignment with broader societal/community logics).

Given that our case is in emerging field of sustainability, professions seem to be playing a stronger role in promoting the sustainability agenda via spreading awareness and training their 
workforce on environmental, sustainability and governance matters. Professional bodies undertake various measures, including training workshops, continuing professional development sessions, special thematic editions of official magazines, articles by foreign and local experts in the field and special reports. According to an ACCA report (2012), "the accountancy profession has an important role in defining and delivering how sustainable development is measured and reported ... environmental and sustainability reporting can provide a mechanism for reviewing whether we are keeping our commitments and can allow us to exchange this information in a transparent manner." Following in the footsteps of the ACCA, both Pakistani accountancy bodies (the Institute of Chartered Accountants of Pakistan and the Institute of Cost Management Accountants of Pakistan) have introduced awards recognizing best practice in sustainability reporting. These award schemes are concerned not with performance and impact, but with disclosure, thereby rewarding transparency.

Sustainability matters are also being incorporated into the syllabus to ensure that the next generation of accountants and business professionals is well informed and can impact on the practices of the institutions for which they work. This was revealed by the head of a global professional accounting body operating in Pakistan:

I think there is a professionalization going on around the workforce so that accountants are better educated in the way of sustainability matters ... so they are better trained and are more capable ... The very least we can do is to have strong advocacy programmes ... Through conferences, seminars and symposiums we can add to people's knowledge, and I think that adding to that knowledge will change their behaviours, which eventually will change the behaviours of the institutions they work for (Country Head, Foreign Professional Accountancy Body).

Overall, professional associations are spreading the sustainability reporting discourse and are an important source of normative pressure for the emergence and development of sustainability reporting in Pakistan. Professional logics also tend to drive sustainability reporting in more established fields (Thijssens et al., 2016) but it clearly playing even stronger role in Pakistan exhibiting sign of sustainability field yet to take its foothold in Pakistani corporate psyche.

\subsection{Practice Driven by Responsibility Logics: Community}

Thornton et al. (2012) suggest that actors often focus on common values and social fit, and seek authority from local communities and/or community organizations that determine norms and values for community welfare. Community logics provide an important rationale for practices to improve collective welfare, achieved through their positive impact on business, society and the environment (Thornton et al., 2012, p. 73). Analysis of our interviews and documentary evidence reveals that those prioritizing community logics advocated "responsibility" as the main basis for sustainability reporting. As shown in Table 2, in our conversations, organizational actors drew on responsibility, accountability to wider society, sustainable performance and social welfare. For instance, one of our respondents said that "operating responsibly is the key driver behind our business processes and we are committed to creating a better workplace, a cleaner environment and progressive communities" (Executive Corporate Communication and CSR, Company H, Fertilizers), and "this [sustainability reporting] brings the organization into a league (elite) of companies where everybody looks at that organization differently as a more responsible, more ethical organization" (Deputy Manager CSR, Company G, Fertilizers).

With regard to wider community and social development, sustainable development was articulated by companies in their reports and by other interviewees during our conversations. Companies articulated these discourses in their sustainability reports: "conducts itself as a responsible corporate entity focused on becoming a partner in sustainable development" (Sustainability Report, Company G, Fertilizers). The responsibility logic focuses attention on 
societal impacts, better behaviour and sustainability performance. Rather than increasing the number of disclosures and transparency about business improvements, proponents of the responsibility logic believe that the value of sustainability reporting lies in driving better sustainability behaviour and performance and societal impact. Several interviewees confirmed this approach: "We want to measure the impact that we are creating in the society. The report will help us to know the impact of initiatives that we're doing or taking up for the betterment of the society" (Executive Corporate Communication and CSR, Company H, Fertilizers); "We're committed to reducing our impact on the planet ... That's why we aim to integrate sustainability into every area of our business" (Sustainability Report, Company G); and "the value of sustainability reporting lies in gauging the impacts of the various sustainability initiatives taken by the organization on the society as a whole" (CEO, Institute on Corporate Governance).

Proponents of the responsibility logic do not reject the business case for sustainability. However, they do question the dominant market-corporate-business logic by emphasizing "responsibility" (University Professor), typically in relation to stakeholder value. A Head of Corporate Communication (Company D, Engineering) said: "I think one of the reasons for sustainability reporting is to let shareholders know that [Company D] is a responsible company." These narratives were also observed in sustainability reports; for example "Our aim is to increase stakeholder value by delivering sustainable solutions to our customers and we consider that essential towards the success of our Company" (Sustainability Report, Company E) and "Sustainability is a collective process in which all stakeholders must come together for the common good. We have been reporting our performance as a responsible company with respect to the communities within which we operate, the environment and people" (Sustainability Report, Company F). Responsibility to wider society expands the accountability relationship between companies and communities, as reflected in a comment by an Executive, Corporate Communication and CSR (Company H, Fertilizers):

When you publish [a] sustainability report, stakeholders become more aware of what is wrong and what is right. So a person who is working on your environment, he sees something which the company is not doing or according to what is published it isn't doing. He becomes aware of that, so he raises an issue.

The arguments advanced by some key protagonists of sustainability reporting centred around the well-being of the wider community and society. They suggested that requiring companies to report on their social and environmental performance raises the visibility and importance of these issues to managers as well as to community organizations. This increased visibility puts more pressure on organizations and makes them more accountable for their sustainability performance.

\subsection{Practice Driven by Regulation: State}

The roles of the state and regulations were emphasized by our interviewees. Sustainability reporting is not mandatory in Pakistan. Our interviews with organizational actors highlighted compliance with voluntary regulations and economic incentives offered by regulatory bodies as reasons for engaging with the sustainability agenda. Several regulations emphasize aspects of requirements for corporate sustainability initiatives, including the Pakistan Environmental Protection Act (1997), the Security Exchange Commission of Pakistan (SECP) General Order for Corporate Social Responsibility (2009), the Code of Corporate Governance (2012) and the Corporate Social Responsibility Voluntary Guidelines (2013). Reflecting on our concept of institutional logics, we argue that these motivations are rooted in the regulatory logic derived from the state order.

The main regulator, SECP, wishes to make sustainability reporting mandatory for all listed companies. This was reflected in a senior official's comment that mandatory regulation "is the 
ultimate solution for raising transparency and accountability of the companies towards sustainability performance" (Commissioner, SECP). A focus on "regulation" for corporate accountability, responsible business and sustainable growth in Pakistan came through strongly in our conversations with regulators, and also in guidelines. For instance, in 2009 SECP issued a mandatory CSR General Order stating that listed companies must include monetary and descriptive disclosures of CSR activities in their directors' reports. However, apart from a tentative list of disclosures, the Order contained no requirement on what to disclose and how to disclose it. As revealed by one of the interviewees, "the focus of the order was on disclosure of spending rather than the process and the impact" (Founder, CSR Advocacy Firm). Companies are free to choose the content of CSR activities in directors' reports. As a result, there is a strong perception among stakeholders that these reports are mainly a public relations tool rather than a tool for accountability.

In addition to the mandatory directors' report on CSR, SECP later developed voluntary CSR guidelines, focusing on processes, committees, policy, goals and achievements, disclosure and reporting, and independent assurance of CSR performance. These guidelines were proposed as a framework to facilitate sustainable growth, responsible business behaviour and corporate accountability (SECP, 2012). A draft version of these guidelines was released for stakeholder comments, and stakeholder round-table discussions were conducted before finalizing them. Their reporting format is voluntary, but the chief regulator acknowledged that SECP intends to further regulate sustainability reporting, making it mandatory for all listed companies.

Our conversations with key actors revealed an underlying debate on whether current regulation of sustainability reporting is sufficient and whether it should be made mandatory. Some interviewees, representing professional bodies and CSR consultants, believed that mandatory reporting would be in the public interest, especially in a country characterized by low stakeholder pressure. However, others did not view mandatory sustainability reporting as a panacea. Many businesses perceive it to be unnecessary and costly. The prevailing managerial attitude is to comply only if legally bound to do so, and they do not want mandatory regulation. They believe that making sustainability reporting mandatory might open new doors for corruption, as the state apparatus lacks resources and is very weak in enforcement.

There was a perception among interviewees that in the absence of direct benefits from sustainability reporting, and with more regulation, companies might quit the stock market. This was explained by a senior official of the leading stock exchange in Pakistan, who believed in incentivizing companies to engage in sustainability reporting:

The real success will depend when, in addition to regulation, we are able to incentivize [the] corporate sector with the benefit of reporting ... Otherwise, because of more compliance and its associated costs as compared to the benefits, [a] larger number of companies will exit the stock market, which means that you are going to encourage the undocumented economy (CEO, Stock Exchange).

One interviewee suggested that these benefits might take the form of tax incentives: "[what] I've suggested is that instead of taking a regulator route, the government should allow tax exemptions to the companies who are involved in CSR activities and its reporting" (Research Associate, Institute on Sustainable Development). Another suggested reputational gains by ranking top-performing companies: "I think to encourage sustainability reporting, it should be included in the criteria for the selection of KSE TOP 25 or TOP 100 companies" (Director Enforcement, Regulatory Body). There was a perception that making such reporting mandatory might have the unintended consequence of increasing corruption and symbolic and tick-box compliance: "Non-reporters should be encouraged through incentives because force never really works here in this country. Non-reporters will find a way around if they do not really want to do it. It will be all on paper, but it will not be in practice" (Head of Corporate Communication, Company D, Engineering). 
Similar perceptions are evident in more established sustainability fields. Corporate social responsibility is regulated and monitored through national norms of governance for responsible business activities (Jamali et al., 2017). However, in some countries, governments incentivize corporate social responsibility and/or partnering with companies for societal welfare (Jamali et al., 2017). There is a fundamental belief that sustainability reporting enables the achievement of sustainable development goals (Bebbington and Unerman, 2018). There is evidence that companies engage in sustainability reporting as a compliance activity (Farooq and De Villiers, 2019), as well as to prevent and/or shape future regulation (Higgins and Coffey, 2016; Larrinaga-Gonzalez and Bebbington, 2001).

\section{Logics, Practice Variation and Emerging Field}

This section highlights linkages between the logics employed and variations in reporting practices in an emerging field, extending debate on variations in sustainability practices. Drawing on the institutional logics perspective, it is argued that logics vary with the institutional order, and there may be multiple institution-based logics in a given context (Lounsbury, 2008). These multiple logics may lead to practice variations, as each logic has a different reference system and vocabulary of motives for action (Goodrick and Reay, 2011). Wide variations in sustainability reporting practices can be explained by the varying influence of different institutional logics and organizational responses to these logics in an emerging field. The maturity of the field must be taken into consideration. We elaborate on this below.

Previous research suggests that business logics (a combination of market and corporation logics) drive sustainability reporting practices. These focus on public relations and reputation management, relying on a solely external perspective of selective and positive reporting and window dressing. As shown in Table 2, this is evident in the case of company $\mathrm{B}$, where public relations mainly drives sustainability reporting. Company B's sustainability reporting practices operate within its public relations department, and a public relations agency is involved in writing the content of its sustainability report. Companies that draw on business logics see sustainability reporting as the responsibility of mainline business units, such as accounting, finance, marketing or public relations departments (Glynn and Raffaelli, 2013). It has been argued that these departments' focus on profit seeking, public relations and reputation makes them more important internal actors in assessing and deciding on sustainability projects and measures (Schaltegger and Hörisch, 2017). Sustainability strategies underpinned by business logics revolve around how firms can benefit financially from addressing societal concerns (Carroll and Shabana, 2010; Gao and Bansal, 2013). This was observed in companies B, E and $\mathrm{F}$, which have sustainability strategies that emphasize business benefits. Under business logics, companies are more likely to follow global standards for sustainability reporting such as the GRI, as these standards are primarily a tool for sustainability, reputation and brand management (Brown et al., 2009).

Transparency logics tend to drive sustainability reporting to take an outside-in approach. In this approach, sustainability reporting practices are strongly influenced by reporting requirements and standards (Thijssens et al., 2016). This was also evident in our cases, as Companies $\mathrm{C}, \mathrm{F}$, and $\mathrm{G}$ follow outside-in approaches driven by sustainability reporting guidelines, frameworks and award schemes, linked mainly with a transparency logic driven by the professions. The outside-in perspective is of primary relevance, and the internal organization of information management and reporting is aligned to meet external requirements, reporting standards and stakeholder demands. Awards for excellent sustainability reporting or consideration for social responsibility investment funds are drivers of companies' internal performance measurement and management, as well as strategy development (Maas et al., 2016). In the outside-in approach, reporting-driven sustainability accounting, external guidelines, and rating and assessment schemes define the information 
requirements and indicators, which in turn guide the accounting methods and systems. The transparency logic drives companies to adhere to international reporting frameworks such as the GRI (Arena et al., 2018), as reflected in companies A, C, F, G and H. When underpinned by a transparency logic, companies' sustainability strategies (e.g. companies A and D) emphasize accountability, sustainable value creation and leadership. Most reporting schemes and reporting awards (such as the GRI) reward transparency (Thijssens et al., 2016) rather than actual performance. The transparency logic drives companies to involve management consultants, accounting professionals and communication experts in implementing sustainability reporting guidelines. In our case, companies A, D, E, F housed their sustainability practices in their corporate communications and corporate branding departments. In one case (C), sustainability reporting was the responsibility of Health, Safety, Environment and Quality (HSEQ), where professional engineers were involved in managing various aspects of sustainability reporting. Management consultants and Big Four accounting firms were involved in providing consultancy services to companies $\mathrm{F}, \mathrm{G}$ and $\mathrm{H}$.

Previous research has argued that the responsibility logics deriving from community order aims to increase organizational sustainability performance to achieve the societal goal of sustainable development (Adams and Whelan, 2009; Adam and McNicholas, 2006; Kok et al., 2019; Thijssens et al., 2016). This performance-oriented and society-oriented perspective on sustainability reporting implies a twin-track approach (Burritt and Schaltegger, 2010) in which sustainability reporting is both strategy-driven and stakeholder-oriented. In our case, Company E followed a twin-track approach, which can be linked to the responsibility logic. The company had crafted its own sustainability framework, which drove its sustainability reporting, as well as its stakeholder processes and external guidelines. A sustainability strategy underpinned by a responsibility logic focuses specifically on a company's contribution to the communities with which it interacts and influences (Arena et al., 2018). Stakeholder empowerment and involvement in committees, decision processes and organizational development are constitutive of the company's philosophy and strategy.

Sustainability strategies underpinned by a responsibility logic emphasize sustainable development and responsible business conduct, as observed in the case of companies $\mathrm{G}$ and $\mathrm{H}$. From the community point of view, sustainability reporting expands the accountability relationship between companies and communities (Higgins and Coffey, 2016). Materially, this should be reflected in the quantification of targets and stakeholder engagement processes, as was the case for companies A, C, E and G. Previous studies suggest that when adopting practices reflecting a community order/responsibility logics, organizations will locate them in non-mainstream business units, such as CSR departments, or corporate or philanthropic foundations (Glynn and Raffaelli, 2013). Standalone CSR departments can be seen as a manifestation of a responsibility logic (Arena et al., 2018). In our case, companies $\mathrm{G}$ and $\mathrm{H}$ housed their sustainability practices in separate CSR departments, and also involved specialist CSR consultancy firms as consultants, another practice linked with the responsibility logic.

According to previous research, state regulations and incentives drive sustainability reporting practices (Jamali et al., 2017). In our case, only Company D was following a compliance approach driven by state rules and regulations. Companies are either compelled to adopt sustainability reporting as a compliance exercise, or are incentivized through awards for demonstrating best practices. This also drives companies to prepare their sustainability reports at the minimum possible cost (Farooq and de Villiers, 2019) simply for compliance or to avoid future regulation (Higgins and Coffey, 2016). However, in developing and emerging economies characterized by complicated governance structures, the state partners with companies for societal welfare, and establishes incentives and awards to encourage specific practices (Jamali et al., 2017). In either case, reporting practices will vary according to the requirements of the particular regulation or award scheme. This was observed in our case, 
where national regulations such as voluntary guidelines on corporate social responsibility reporting and national and international award schemes drove sustainability reporting practices in a limited fashion. In terms of structure, national regulations require companies to separate responsibility, for example with standalone CSR departments. In terms of systems and procedures, companies are required to follow the procedures stated in the regulatory guidelines and other relevant sustainability reporting standards. There is a requirement to devise mechanisms to incorporate stakeholder inputs into the reporting process, as well as undergoing external assurance of sustainability reporting. In our case, only one sustainability report (company D) mentioned local guidelines on corporate social responsibility and sustainability issues, by the Securities and Exchange Commission of Pakistan.

The above discussion demonstrates a wide variety of logics and their influences on reporting practices. Reflection on features of emerging fields provides us with some understanding. Unsurprisingly, organizational practices vary, but such variations are relatively small in mature/established fields. In contrast, variations in sustainability reporting are likely to be more pronounced in emerging fields, as noted in institutional studies. These are detailed below.

First, mature or established fields typically exhibit high levels of interaction dominated by a few players who establish the norms. Emerging fields tend to show fewer interactions but with multiple players trying to establish dominance. We find that professional bodies, including various local and international professional associations and networks, drive the sustainability reporting agenda in Pakistan. In addition, multiple state actors and international standards bodies, such as the GRI, shape sustainability reporting through regulations and guidelines. Unsurprisingly, this leads to a multiplicity of practices in terms of approach, strategy, structure, guidelines, quantification of targets and stakeholder engagements, as shown in Table 1. Second, institutional studies also claim that in emerging fields, participants do not share a common identity, and accordingly the field lacks a common purpose for existence. This was a common theme in our conversations, as sustainability reports are organization-specific. In addition, organizations tend to consider existing institutions (Dacin, 1997), which produce disparate sustainability practices with multiple logics. Third, we find complex and multiple versions of sustainability, as information sharing on sustainability is almost non-existent in Pakistan. We did find evidence of a "Best Sustainability Report" prize to enhance information flow across constituents, but this has not had any significant impact on companies in terms of developing a similar focus, nor on the uptake of sustainability reporting in Pakistan. Fourth, we also find, unsurprisingly, a push for a business case for promoting the sustainability agenda. This has been promoted by professional bodies such as the ACCA in Pakistan, as well as selling the idea of transparency in sustainability reporting. Coupled with this, the state is also involved in promoting the sustainability agenda through mandatory and voluntary measures, invoking the benefits of regulations. Community (responsibility logic) order drives some sustainability reporting practices. External influence is also present and plays a role in shaping the logics of sustainability reporting. For instance, the logic of transparency is activated by sustainability practitioners and promoted by professional bodies and international financial and accounting institutions. In the main, we find no dominant logic but many players involved, as expected in an emerging field.

\section{Concluding Remarks}

Returning to our first question relating to how sustainability reporting varies, we have found that reporting practices vary significantly in companies that engage with sustainability. As shown in Table 1, reporting varies in terms of its approach, its emphasis on sustainability strategies, the leading departments involved, the involvement of consultants, sustainability reporting guidelines and assurance, stakeholder engagement and sustainability targets. This is 
unsurprising as an emerging field is, by default, a blank space for multiple players to shape social practices. Sustainability reporting is one such space occupied by multiple and often contradictory logics, resulting in practice variations. With regard to our second question, relating to the logics underlying motivations for sustainability reporting, Table 2 clearly demonstrates that motivations and their underlying logics emanate from social and institutional orders. Institutional orders, including market/corporation, profession, community and state, produce business, transparency, responsibility and regulatory logics, respectively. We have shown how each of these logics underlies differing motivations for businesses to engage in sustainability reporting.

Returning to our third question relating to how the logics contribute to variations in reporting, this link is clearly demonstrated in our case (Table 2). We have argued that the presence of multiple logics reflects the heterogeneous context and institutional complexity, which are the main source of variations in sustainability reporting practices. For instance, companies driven by business logics employ a solely external-facing approach, employing a business case strategy for sustainability reporting. The public relations department takes charge of producing these reports for only a few key stakeholders. In contrast, companies driven by a transparency logic take an outside-in approach, employing a sustainable value creation strategy for their sustainability agenda. Accountancy firms are given responsibility, and adopt GRI guidelines in carrying out the reporting on the companies' behalf. A community order gives primacy to responsibility and societal impacts, while a state order focuses on regulation and sustainable development. In brief, each of these logics, driven by broader institutional orders, shapes companies' sustainability agendas and produces different sustainability reporting approaches, strategies, structures and guidelines.

This paper makes three contributions. First, it contributes to the debate on motivations and variations in sustainability reporting. Sustainability studies focus mainly on motivations for sustainability rather than how these motivations might be linked with underlying logics and practice variations. Similarly, with a few exceptions, practice variations have been studied without solid theoretical explanations. In contrast, in their study of integrated reports, Cerbone and Maroun (2019) argue that how logics are instantiated may explain the considerable variation observed in integrated reports. Building on this, this paper demonstrates that institutional orders and motivations for underlying logics provide a deeper explanation of why companies adopt a variety of sustainability reporting modes in the same context. This is crucial partly because previous studies typically conceptualize practice variations as stemming from strategic or institutional demands. In this paper, we conceive sustainability as an emerging field in which multiple logics are activated by their proponents, explaining practice variations.

Following from this, we make a second contribution in demonstrating the value of the concept of "institutional logics" for explaining the source of practice variations, recognizing that institutional contexts are characterized by the coexistence of multiple logics deriving from institutional orders. Drawing on institutional studies, accounting researchers have demonstrated how logics shape organizational responses (Safari et al., 2020; Golyagina, 2019; Yee, 2020; Conrath-Hargreaves and Wüstemann, 2019). Yet, as Contrafatto et al. (2019) note, relatively little attention has been paid to the likelihood that logics drive accounting practices, including sustainability reporting. More specifically, accounting researchers have paid little attention to how loosely defined institutional arrangements, unclear institutional rules and sharp contestation between logics in an emerging field may drive greater practice variation at the organizational level (Vican and Pernell-Gallagher, 2013). In our case, we have explored corporate motives and their underlying logics for advancing the sustainability agenda, and crucially how actors instantiate their logics for sustainability reporting when these are yet to be established and institutionalized in wider society. In particular, practice variations in an 
emerging field allow us to shed light on the lack of a dominant logic, and on how multiple players attempt to shape very diverse reporting practices, promoting multiple logics.

Our third contribution arises from the research context, which is that of a developing nation. As the sustainability field is still emerging in most countries, especially developing economies, it is important to show how diversity in sustainability reporting practices emerges. Our case reveals a variety of sustainability reporting modes. Similarity of reporting is the exception rather than the rule in this emerging field. We also find a variety of motives for sustainability reporting. Studies in developing nations point predominantly to the role of global and local actors such as multinational corporations, donor agencies and professional bodies in shaping corporate social responsibility agendas (Rahaman et al., 2004; Belal and Owen, 2007; Islam and Deegan, 2008; Momin and Parker, 2013; Beddewela and Herzig, 2013). Building on this, we argue that the role of professional bodies, sponsored by donor agencies, is critical to companies' sustainable agendas. We have demonstrated that professions seem to play a stronger role in promoting business and transparency logics in reporting.

Finally, we wish to reflect on some important practical implications especially for an emerging field. Understanding the conditions that influence corporate decision makers' logics will provide additional insights into what motivates firms to engage in the practice of sustainability reporting. In a societal context that lacks sustainability awareness and interest at the socio-political level, promoting sustainability reporting through business logics seems essential, as it motivates firms to engage. However, it is necessary to understand the limitations of the business case for wider societal impacts, which may result in the disclosure of selective and partial social and environmental information. Sustainability reporting developed or applied more extensively in this way will lead to its use for advertising, branding, public relations and image construction, rather than its intended use for increasing transparency, accountability and sustainability performance. Therefore, wider engagement, especially with non-business actors such as community organizations, environmentalists and academics, is required to enable more informed debates about the roles of the market and corporate logics and, of course, their limits. At the same time, there is a need to improve stakeholder awareness of social and environmental sustainability issues so that they can influence reporting practices.

\section{References}

Adam, C. and McNicholas, P. (2006), "Making a difference: Sustainability reporting, accountability and organizational change", Accounting Auditing \& Accounting Journal, Vol. 20 No. 3, pp. 382-402.

Adams, C. A. (2002), "Internal organisational factors influencing corporate social and ethical reporting: beyond current theorising", Accounting, Auditing \& Accountability Journal, Vol. 15 No. 2, pp. 223-250.

Adams, C. A. (2004), "The ethical, social and environmental reporting-performance portrayal gap", Accounting, Auditing \& Accountability Journal, Vol. 17 No. 5, pp. 731-757.

Adams, C. A., Larrinaga-González, C., Belal, A. R. and Owen, D. L. (2007), "The views of corporate managers on the current state of, and future prospects for, social reporting in Bangladesh", Accounting, Auditing \& Accountability Journal.

Adams, C. A. and Whelan, G. (2009), "Conceptualising future change in corporate sustainability reporting", Accounting, Auditing \& Accountability Journal, Vol. 22 No. 1, pp. 118-143.

Arena, M., Azzone, G. and Mapelli, F. (2018), "What drives the evolution of Corporate Social Responsibility strategies? An institutional logics perspective", Journal of cleaner production, Vol. 171, pp. 345-355.

Ashraf, J. and Ghani, W. I. (2005), "Accounting development in Pakistan", The International Journal of Accounting, Vol. 40 No. 2, pp. 175-201. 
Bebbington, J. (2001), "Sustainable Development: A Review of the International Development, Business and Accounting Literature", Accounting Forum, Vol. 25 No. 2, p. $128 * 157$.

Bebbington, J., Larrinaga, C. and Moneva, J. M. (2008), "Corporate social reporting and reputation risk management", Accounting, Auditing \& Accountability Journal, Vol. 21 No. 3, pp. 337-361.

Bebbington, J. and Unerman, J. (2018), "Achieving the United Nations Sustainable Development Goals: an enabling role for accounting research", Accounting, Auditing \& Accountability Journal, Vol. 31 No. 1, pp. 2-24.

Beddewela, E. and Herzig, C. (2013), "Corporate social reporting by MNCs' subsidiaries in Sri Lanka", in Accounting Forum, Vol. 37, pp. 135-149.

Belal, A. R. and Cooper, S. (2011), "The absence of corporate social responsibility reporting in Bangladesh", Critical perspectives on accounting, Vol. 22 No. 7, pp. 654-667.

Belal, A. R. and Owen, D. L. (2007), "The views of corporate managers on the current state of, and future prospects for, social reporting in Bangladesh: an engagement based study", Accounting, Auditing and Accountability Journal, Vol. 20 No. 3, pp. 472-494.

Bouten, L. and Everaert, P. (2014), "Social and environmental reporting in Belgium: 'Pour vivre heureux, vivons cachés'", Critical Perspectives on Accounting, No. 0.

Brown, H. S., de Jong, M. and Levy, D. L. (2009), "Building institutions based on information disclosure: lessons from GRI's sustainability reporting", Journal of cleaner production, Vol. 17 No. 6, pp. 571-580.

Buhr, N. (1998), "Environmental performance, legislation and annual report disclosure: the case of acid rain and Falconbridge", Accounting, Auditing \& Accountability Journal, Vol. 11 No. 2, pp. 163-190.

Buhr, N. (2002), "A structuration view on the initiation of environmental reports", Critical Perspectives on Accounting, Vol. 13 No. 1, pp. 17-38.

Buhr, N., Gray, R. and Milne, M. J. (2014), "Histories, rationales, voluntary standards and future prospects for sustainability reporting", in Bebbington, J., Unerman, J. and O'Dwyer, B. (Eds.) Sustainability accounting and accountability, p. 51.

Burritt, R. L. and Schaltegger, S. (2010), "Sustainability accounting and reporting: fad or trend?", Accounting, Auditing \& Accountability Journal, Vol. 23 No. 7, pp. 829-846.

Byrch, C., Kearins, K., Milne, M. and Morgan, R. (2007), "Sustainable "what"? A cognitive approach to understanding sustainable development", Qualitative Research in Accounting \& Management, Vol. 4 No. 1, pp. 26-52.

Carlsson-Wall, M., Kraus, K. and Messner, M. (2016), "Performance measurement systems and the enactment of different institutional logics: insights from a football organization", Management Accounting Research, Vol. 32, pp. 45-61.

Carroll, A. B. and Shabana, K. M. (2010), "The business case for corporate social responsibility: A review of concepts, research and practice", International journal of management reviews, Vol. 12 No. 1, pp. 85-105.

Channuntapipat, C., Samsonova-Taddei, A. and Turley, S. (2019), "Exploring diversity in sustainability assurance practice: Evidence from assurance providers in the UK", Accounting, Auditing \& Accountability Journal, Vol. 32 No. 2, pp. 556-580.

Conrath-Hargreaves, A. and Wüstemann, S. (2019), "Multiple institutional logics and their impact on accounting in higher education", Accounting, Auditing \& Accountability Journal.

Contrafatto, M., Costa, E. and Pesci, C. (2019), "Examining the dynamics of SER evolution: an institutional understanding", Accounting, Auditing \& Accountability Journal.

Cerbone, D. and Maroun, W. (2019), Materiality in an integrated reporting setting: Insights using an institutional logics framework. The British Accounting Review, 52, 100876. 
Currie, G. and Spyridonidis, D. (2016), "Interpretation of Multiple Institutional Logics on the Ground: Actors' Position, their Agency and Situational Constraints in Professionalized Contexts", Organization Studies, Vol. 37 No. 1, pp. 77-97.

Dacin, M. T. (1997), "Isomorphism in context: The power and prescription of institutional norms", Academy of Management Journal, 40: 46-81.

Deegan, C. (2002), "Introduction: The legitimising effect of social and environmental disclosures-a theoretical foundation", Accounting, Auditing \& Accountability Journal, Vol. 15 No. 3, pp. 282-311.

Deegan, C. and Blomquist, C. (2006), "Stakeholder influence on corporate reporting: An exploration of the interaction between WWF-Australia and the Australian minerals industry", Accounting, Organizations and Society, Vol. 31 No. 4, pp. 343-372.

Deloitte . (2012). "Sustainability reporting in Pakistan". Retrieved from https://www2.deloitte.com/content/dam/Deloitte/pk/Documents/sustainabilityreporting-in-pakistan.pdf.

DiMaggio, P.J. and Powell, W.W. (1983), "The iron cage revisited: Institutional isomorphism and collective rationality in organizational fields", American sociological review, pp.147-160.

Ezzamel, M., Robson, K. and Stapleton, P. (2012), "The logics of budgeting: Theorization and practice variation in the educational field", Accounting, Organizations and Society, Vol. 37 No. 5, pp. 281-303.

Farooq, M. B. and de Villiers, C. (2019), "Understanding how managers institutionalise sustainability reporting: Evidence from Australia and New Zealand, Accounting", Accounting, Auditing \& Accountability Journal. Vol. 32 No. 5, pp. 1240-1269.

Gao, J. and Bansal, P. (2013), "Instrumental and integrative logics in business sustainability", Journal of Business Ethics, Vol. 112 No. 2, pp. 241-255.

Gao, S. S., Heravi, S. and Xiao, J. Z. (2005), "Determinants of corporate social and environmental reporting in Hong Kong: a research note", in Accounting Forum, Vol. 29 , pp. 233-242.

Giddens, A. 1979. "Central problems in social theory: Action, structure and contradiction in social analysis", Berkeley: University of California Press.

Glynn, M. A. and Raffaelli, R. (2013), "Logic pluralism, organizational design, and practice adoption: The structural embeddedness of CSR programs", Institutional Logics in Action, Part B, Emerald Group Publishing Limited, pp. 175-197.

Golyagina, A. (2020). "Competing logics in university accounting education in postrevolutionary Russia", Critical perspectives on Accounting, 69, 102090.

Goodrick, E. and Reay, T. (2011), "Constellations of Institutional Logics: Changes in the Professional Work of Pharmacists", Work and Occupations, Vol. 38 No. 3, pp. 372416.

Gray, B. (1985). "Conditions facilitating interorganizational collaboration", Human Relations, 38(10), 911-936.

Gray, R., Kouhy, R. and Lavers, S. (1995), "Corporate social and environmental reporting: a review of the literature and a longitudinal study of UK disclosure", Accounting, Auditing \& Accountability Journal, Vol. 8 No. 2, pp. 47-77.

Greenwood, R., Díaz, A. M., Li, S. X., and Lorente, J. C. (2010), "The multiplicity of institutional logics and the heterogeneity of organizational responses". Organization science, 21(2), 521-539.

Greenwood, R., Suddaby, R., \& Hinings, C. R. (2002), "The role of professional associations in the transformation of institutionalized fields". Academy of Management Journal, 45: 58-80. 
Guerreiro, M. S., Rodrigues, L. L. and Craig, R. (2012), "Voluntary adoption of International Financial Reporting Standards by large unlisted companies in Portugal-Institutional logics and strategic responses", Accounting, Organizations and Society, Vol. 37 No. 7, pp. 482-499.

Herremans, I. M., Herschovis, M. S. and Bertels, S. (2009), "Leaders and laggards: The influence of competing logics on corporate environmental action", Journal of Business Ethics, Vol. 89 No. 3, pp. 449-472.

Higgins, C. and Coffey, B. (2016), "Improving how sustainability reports drive change: a critical discourse analysis", Journal of cleaner production, Vol. 136, pp. 18-29.

Higgins, C. and Larrinaga, C. (2014), "Sustainability reporting Insights from Institutional Theory", in Bebbington, J., Unerman, J. and O'Dwyer, B. (Eds.) Sustainability accounting and accountability, Routledge, pp. 273-286.

Holm, P. (1995), "The dynamics of institutionalization: Transformation processes in Norwegian fisheries", Administrative Science Quarterly, 40: 398-422.

Islam, M. A. and Deegan, C. (2008), "Motivations for an organisation within a developing country to report social responsibility information", Accounting, Auditing \& Accountability Journal.

Islam, M. A. and Deegan, C. (2010), "Media pressures and corporate disclosure of social responsibility performance information: a study of two global clothing and sports retail companies", Accounting and business research, Vol. 40 No. 2, pp. 131-148.

Jamali, D., Karam, C., Yin, J. and Soundararajan, V. (2017), "CSR logics in developing countries: Translation, adaptation and stalled development", Journal of World Business, Vol. 52 No. 3, pp. 343-359.

Khan, A., \& Khan, R. (2004), "Drivers of change Pakistan", Retrieved from http://www.researchcollective.org/Documents/Civil_Society_And_Social_Change In Pakistan.pdf

Kok, A.M., de Bakker, F.G. and Groenewegen, P. (2019), "Sustainability struggles: Conflicting cultures and incompatible logics", Business \& Society, 58(8), pp.14961532.

KPMG (2013), "The KPMG Survey of Corporate Responsibility Reporting 2013", Retrieved from https://assets.kpmg/content/dam/kpmg/pdf/2013/12/corporate-responsibilityreporting-survey-2013.pdf

Lander, M. W., Koene, B. A. and Linssen, S. N. (2013), "Committed to professionalism: Organizational responses of mid-tier accounting firms to conflicting institutional logics", Accounting, Organizations and Society, Vol. 38 No. 2, pp. 130-148.

Larrinaga-Gonzalez, C. and Bebbington, J. (2001), "Accounting change or institutional appropriation?-A case study of the implementation of environmental accounting", Critical perspectives on accounting, Vol. 12 No. 3, pp. 269-292.

Lepori, B., and Montauti, M. (2020), "Bringing the organization back in: Flexing structural responses to competing logics in budgeting", Accounting, organizations and society, 80, 101075.

Lieven, A. (2012), Pakistan: a hard country, Penguin Books.

Lodhia, K. S. (2003), "Accountants' Responses to the Enviromental Agenda in a Developing Nation: An Intial and Exploratory Study on Fiji", Critical Perspectives on Accounting, Vol.14, pp. 715-737.

Lounsbury, M. (2007), "A tale of two cities: Competing logics and practice variation in the professionalizing of mutual funds", Academy of management journal, 50(2), 289-307.

Lounsbury, M. (2008), "Institutional rationality and practice variation: New directions in the institutional analysis of practice", Accounting, Organizations and Society, Vol. 33 No. 4, pp. 349-361. 
Lounsbury, M. and Crumley, E. T. (2007), "New practice creation: An institutional perspective on innovation", Organization Studies, Vol. 28 No. 7, pp. 993-1012.

Maas, K., Schaltegger, S. and Crutzen, N. (2016), "Integrating corporate sustainability assessment, management accounting, control, and reporting", Journal of cleaner production, Vol. 136, pp. 237-248.

Madsen, C. U. and Waldorff, S. B. (2019), "Between advocacy, compliance and commitment: A multilevel analysis of institutional logics in work environment management", Scandinavian Journal of Management, Vol. 35 No. 1, pp. 12-25.

Mahmood, Z., Kouser, R., Hassan, I. and Iqbal, Z. (2017), "Why Pakistani Small and Medium Enterprises are Not Reporting on Sustainability Practices?", Pakistan Journal of Commerce \& Social Sciences, Vol. 11 No. 1.

Mahmood, Z., Kouser, R. and Masud, M. A. K. (2019), "An emerging economy perspective on corporate sustainability reporting-main actors' views on the current state of affairs in Pakistan", Asian Journal of Sustainability and Social Responsibility, Vol. 4 No. 1, p. 8.

Malik, F. and Nicholson, B. (2020), "Understanding the interplay of institutional logics and management practices in impact sourcing", Information Systems Journal, Vol. 30 No. 1, pp. 125-149.

Malik, N. (2014), Corporate Social Responsibility and Development in Pakistan, Routledge.

Momin, M. A. and Parker, L. D. (2013), "Motivations for corporate social responsibility reporting by MNC subsidiaries in an emerging country: The case of Bangladesh", The British Accounting Review, Vol. 45 No. 3, pp. 215-228.

Navis, C., \& Glynn, M. A. (2010), "How new market categories emerge: Temporal dynamics of legitimacy, identity, and entrepreneurship in satellite radio, 1990-2005", Administrative Science Quarterly, 55(3), 439-471.

Ocasio, W. (2011), "Attention to attention", Organization Science, Vol. 22 No. 5, pp. 12861296.

Oliver, C. (1991), "Strategic responses to institutional processes", Academy of management review, Vol. 16 No. 1, pp. 145-179.

Parker, L. D. (2014), "Corporate social accountability through action: Contemporary insights from British industrial pioneers", Accounting, Organizations and Society, No. 0.

Purdy, J.M. and Gray, B. (2009), "Conflicting logics, mechanisms of diffusion, and multilevel dynamics in emerging institutional fields", Academy of Management Journal, 52(2), pp.355-380.

Rahaman, A. S., Lawrence, S. and Roper, J. (2004), "Social and environmental reporting at the VRA: institutionalised legitimacy or legitimation crisis?", Critical perspectives on accounting, Vol. 15 No. 1, pp. 35-56.

Reay, T. and Hinings, C. R. (2009), "Managing the rivalry of competing institutional logics", Organization Studies, Vol. 30 No. 6, pp. 629-652.

Reay, T. and Jones, C. (2015), "Qualitatively capturing institutional logics", Strategic Organization, p. 1476127015589981.

Safari, M., de Castro, V. B., \& Steccolini, I. (2020), "The interplay between home and host logics of accountability in multinational corporations (MNCs): the case of the Fundão dam disaster", Accounting, Auditing \& Accountability Journal.

Sajjad, A. and Eweje, G. (2014), "Corporate Social Responsibility in Pakistan: Current Trends and Future Directions", Corporate Social Responsibility and Sustainability: Emerging Trends in Developing Economies (Critical Studies on Corporate Responsibility, Governance and Sustainability, Volume 8) Emerald Group Publishing Limited, Vol. 8, pp. 163-187. 
Schaltegger, S. and Burritt, R. (2018), "Business cases and corporate engagement with sustainability: Differentiating ethical motivations", Journal of Business Ethics, Vol. 147 No. 2, pp. 241-259.

Schaltegger, S. and Hörisch, J. (2017), "In search of the dominant rationale in sustainability management: legitimacy-or profit-seeking?", Journal of Business Ethics, Vol. 145 No. 2, pp. 259-276.

SECP (2012), "Security Exchange Commission of Pakistan gives nod to CSR guidelines", Retrieved from https://www.secp.gov.pk/wp-content/uploads/2016/05/SECP-givesnod-to-CSR-guidelines.pdf

Soobaroyen, T. and Mahadeo, J. D. (2016), "Community disclosures in a developing country: insights from a neo-pluralist perspective", Accounting, Auditing \& Accountability Journal.

Spence, C. (2009), "Social and environmental reporting and the corporate ego", Business Strategy and the Environment, Vol. 18 No. 4, pp. 254-265.

Spence, C. and Gray, R. (2007), Social and environmental reporting and the business case, Certified Accountants Educational Trust.

Thijssens, T., Bollen, L. and Hassink, H. (2016), "Managing sustainability reporting: many ways to publish exemplary reports", Journal of cleaner production, Vol. 136, pp. 86101.

Thornton, P. H. (2002), "The rise of the corporation in a craft industry: Conflict and conformity in institutional logics", Academy of management journal, Vol. 45 No. 1, pp. 81-101.

Thornton, P. H. (2004), Markets from culture: Institutional logics and organizational decisions in higher education publishing: Stanford University Press.

Thornton, P. H. and Ocasio, W. (2008), "Institutional logics", The Sage handbook of organizational institutionalism, Vol. 840, pp. 99-128.

Thornton, P. H., Ocasio, W. and Lounsbury, M. (2012), The institutional logics perspective: A new approach to culture, structure, and process, OUP Oxford.

van Bommel, K. (2014), "Towards a legitimate compromise? An exploration of integrated reporting in the Netherlands", Accounting, Auditing \& Accountability Journal, Vol. 27 No. 7, pp. 1157-1189.

Vican, S. and Pernell-Gallagher, K. (2013), "Instantiation of institutional logics: The "business case" for diversity and the prevalence of diversity mentoring practices", Institutional Logics in Action (Research in the Sociology of Organizations). Research in the Sociology of Organizations. Emerald Group Publishing Limited, pp. 233-273.

Waheed, A. (2005), "Evaluation of the state of corporate social responsibility in Pakistan and strategy for implementation", A report written for Securities and Exchange Commission of Pakistan, Responsible Business Initiative.

Yee, H. (2020), "Institutional logics and institutional work: radical reform of the Chinese public accounting profession in the 1990s", Accounting, Auditing \& Accountability Journal.

Yin, R. K. (2014), Case study research: Design and methods, Sage publications.

\footnotetext{
${ }^{1}$ The Pakistan Environmental Protection Act (1997), the SECP (Security Exchange Commission of Pakistan) General Order for Corporate Social Responsibility (2009), the Code of Corporate Governance (2012) and the Corporate Social Responsibility Voluntary Guidelines (2013)

2 Pakistan Compliance Initiative, Responsible Business Initiative, GRI, United Nations Global Compact and the International Federation of Accountants Sustainability Framework
} 

${ }^{3}$ Association of Chartered Certified Accountants (ACCA), Institute of Chartered Accountants of Pakistan and
Institute of Cost Management Accountants of Pakistan
${ }^{4}$ Non-accounting based professional associations include local and international advocacy organizations (e.g.
UNGC, Pakistan Institute of Corporate Governance) operating in Pakistan. 